\title{
SILICON FERTILIZATION IMPROVE YIELD AND QUALITY OF RICE AND PEARL MILLET IN CERRADO SOILS
}

\author{
ADUBAÇÃO SILICATADA AUMENTA A PRODUTIVIDADE E QUALIDADE DE \\ ARROZ E MILHETO EM SOLOS DO CERRADO
}

\section{Raquel de Castro Salomão CHAGAS ${ }^{1}$; Takashi MURAOKA ${ }^{2}$; Gaspar Henrique KORNDÖRFER ${ }^{3}$; Mônica Sartori de CAMARGO ${ }^{4}$}

1. Professor, Doutor, Centro Federal de Educação Tecnológica de Minas Gerais, Campus 1, Belo Horizonte, MG, Brasil; 2. Pesquisador Científico, Doutor, Centro de Energia Nuclear na Agricultura/Universidade de São Paulo- CENA/USP, Piracicaba, SP, Brasil; 3. Professor, Doutor, Instituto de Ciências Agrárias - ICIAG, Universidade Federal de Uberlândia - UFU, Uberlândia, MG, Brasil, Bolsista do CNPq; 4.Pesquisador Científico, Doutor, Agência Paulista de Tecnologia dos Agronegócios (APTA)/Pólo Centro Sul, Piracicaba, SP, Brasil. mscamarg@yahoo.com.br

\begin{abstract}
Although silicon ( $\mathrm{Si}$ ) fertilization in rice (Oryza sativa) plants have already been studied, most of the Brazilian studies have focused on the acidity correction effects of sources and the application rate, but not on Si supply. Moreover, beneficial effects are rarely linked to other Si-accumulation plants such as pearl millet (Pennisetum glaucum), which is extensively grown in low soluble $\mathrm{Si}$ of Cerrado soils. The objective of this study was to evaluate the Si sources and application rates on the yield and quality of two commonly cultivated grain crops (rice and pearl millet) in Cerrado soils. The experiments were conducted on two crops (rice and pearl millet) and two soil types (Rhodic Haplustox-LV and Quartzipsamment-RQ) in a completely randomized factorial scheme with four replicates, four Si rates $(0 ; 200 ; 400$, and $800 \mathrm{~kg} \mathrm{ha}^{-1} \mathrm{Si}$ ); and three sources (calcium and magnesium silicate, wollastonite, and silicic acid). All plots received the same quantities of $\mathrm{Ca}$ and $\mathrm{Mg}$ to equilibrate these levels in both soils. $\mathrm{Ca}$ and $\mathrm{Mg}$ silicate and wollastonite produced linear increases in soluble $\mathrm{Si}\left(0.5 \mathrm{~mol} \mathrm{~L}{ }^{-1}\right.$ acetic acid), in $\mathrm{LV}, \mathrm{RQ}$, and in Si uptake by rice and pearl millet. Increases in shoot dry weight were observed in rice and pearl millet from maximum rates of 542,550 and $480 \mathrm{~kg} \mathrm{ha}^{-1} \mathrm{Si}$ in $\mathrm{RQ}$, respectively. Ca and $\mathrm{Mg}$ silicate levels were higher than wollastonite in the dry weight of both plants.
\end{abstract}

KEY WORDS: Fertilization. Silicate. Graminea. Soil.

\section{INTRODUCTION}

Several benefits of $\mathrm{Si}$ have already been known, although it is not considered to be an essential element for the plants. For rice, which is a Si-accumulation plant (EPSTEIN, 2009), it can lead to an increase in photosynthetic activity, yield (CARVALHO-PUPPATTO et al., 2004; DETMANN et al., 2012), number of grains per panicle (MARCHESAN et al., 2004), quality (MAUAD et al., 2003), tolerance to drought (CHEN et al., 2011), pests (RANGANATHAN et al., 2006; HOSSEIN et al., 2011), and diseases (TATAGIBA et al., 2014).

The area under the Cerrado vegetation in the central region of Brazil occupies 23\% of the area, showing great potential to grain yield and grainproducing grasses. However, several classes of soils are highly weathered, with low $\mathrm{pH}$ and nutrients and Si levels in soil (LOPES, 1996; PEREIRA 2004). In addition, the successive cultivation of graminea with a high Si uptake could reduce the soluble Si levels in soils, which are lower than in temperate countries (Mc KEAGUE; CLINE 1963; FOY, 1992). It could be necessary to provide Si fertilization to these soils to improve grain crop yields.
The intensity of the response to $\mathrm{Si}$ fertilization depends on the levels in soils, sources and application rates. A Si content of less than 9.8 and $13 \mathrm{mg} \mathrm{dm}^{-3}$ soluble in $0.5 \mathrm{~mol} \mathrm{~L}^{-1}$ acetic acid is considered responsive to the application of this element for rice yield (KORNDÖRFER et al., 1999; BARBOSA FILHO et al., 2001). Those levels are specially found in sandy and loamy sandy soils. Slags are the least expensive and most used $\mathrm{Si}$ source used in Brazilian agriculture. Enormous quantities of slags are generated from the steel and iron processing by industries every year.The utilization of this material for agriculture could reduce the environmental problems because larger areas are necessary for its deposition and storage. However, it is important to know the solubility of the slag in soil in order to provide Si to plants, once $\mathrm{Si}$ availability to plants depends on the origin and grain size (PEREIRA et al., 2004, 2010). Regarding the application of Si rates, values lower than $960 \mathrm{~kg}$ $\mathrm{ha}^{-1}$ of $\mathrm{Si}$ are generally used in rice studies (KORNDÖRFER et al., 1999; MAUAD et al., 2003; BARBOSA FILHO et al., 2004).

Several studies conducted have shown positive results of Si fertilization in rice plants in Brazil. However, they focused on the evaluation of 
the acidity correction and $\mathrm{Ca}, \mathrm{Mg}$, and $\mathrm{Si}$ supply under field conditions (BARBOSA FILHO et al., 2001; KORNDÖRFER et al.,2001; CARVALHOPUPPATTO et al.,2003) and pots (PEREIRA et al.,2004; KORNDORFER et al., 1999; CAMARGO et al., 2007b) and only a few studies (RAMOS et al., 2008) have evaluated the benefits of Si supply for the rice crops on its uptake, yield and quality without the additional effects (increasing on $\mathrm{pH}$ and $\mathrm{Ca}$ and $\mathrm{Mg}$ content in soils) of silicate applied in tropical soils. The $\mathrm{Ca}$ and $\mathrm{Mg}$ levels in soil had to be used in the same quantities when different silicate rates were applied in soil, as already done in incubation studies of $\mathrm{Si}$ sources and rates (CAMARGO et al., 2007a; PEREIRA et al., 2007, 2010).

In addition, the beneficial effects of various $\mathrm{Si}$ sources and application rates are rarely linked to other Si-accumulation plants such as the pearl millet (Epstein, 2009). This crop is important to the Cerrado region due to the fact that its utilization as non-tillage and animal feeding (RODRIGUES et al., 2001) and its cultivation area have increased in the last decade. Although the $\mathrm{Si}$ contents in the leaves of pearl millet are lower than those observed in the leaves of rice plants (MITANI; MA, 2005), positive results on the reduction of mildew severity, which is an important disease of this crop, have already been observed when $\mathrm{Si}$ was applied (DEEPAK et al., 2008). Silicon fertilization could improve yield and quality of grains for the pearl millet, as shown in the literature of the rice crops.

Considering the low soluble Si levels in soils under the Cerrado region, and high uptake by the grain crops, studies about the potential benefits of silicon supply are necessary. The objective of this study was to evaluate the $\mathrm{Si}$ sources and application rates on yield and quality of rice and pearl millet (two commonly cultivated crops) in the Cerrado soils.

\section{MATERIAL AND METHODS}

Four experiments were conducted in greenhouses at the Center for Nuclear Energy in Agriculture/USP, Piracicaba, SP $\left(22^{\circ} 42^{\prime} 30^{\prime}\right.$ LS e $47^{\circ} 38^{\prime} 00$ " LW), São Paulo state from October, 2002 to March, 2002. The experiments were entirely randomized with four replicates comprising four silicon application rates $(0,200,400$ and 800 $\left.\mathrm{kg} \mathrm{Si} \mathrm{ha}{ }^{-1}\right)$, three sources: calcium and magnesium silicate $(24.2 \% \mathrm{Si}, 29.5 \% \mathrm{Ca}$, and $1.1 \% \mathrm{Mg})$, wollastonite $(12 \% \mathrm{Si}, 28 \% \mathrm{Ca}$, and $7 \% \mathrm{Mg})$ and pure silicic acid $(29 \% \mathrm{Si})$. These treatments were applied to two crops (rice and millet) and two soil types (Rhodic Haplustox-LV and Typic Quartzipsamment-RQ). Ca and $\mathrm{Mg}$ were added to all pots in order to balance levels throughout all treatments.

Soil chemical analysis of RQ (660 $\mathrm{g} \mathrm{kg}^{-1}$ sand, $60 \mathrm{~g} \mathrm{~kg}^{-1}$ silt and $280 \mathrm{~g} \mathrm{~kg}^{-1}$ clay) revealed: $\mathrm{pH}\left(\mathrm{CaCl}_{2}\right)=3.9$, Si $\left(0.5 \mathrm{~mol} \mathrm{~L}{ }^{-1}\right.$ acetic acid $)=2.0$; $\mathrm{OM}=29 \mathrm{~g} \mathrm{dm}^{-3} ; \mathrm{P}$ anionic exchange resin $=1 \mathrm{mg} \mathrm{dm}$

${ }^{3} ; \mathrm{K}, \mathrm{Ca}, \mathrm{Mg}$, and cation exchange capacity (CEC) $=2.6,13,4$ and $83.6 \mathrm{mmol}_{\mathrm{c}} \mathrm{dm}^{-3}$, basis saturation (V) and $\mathrm{Al}$ saturation $(\mathrm{m})=3.8$ and $23 \%$. Chemical analysis of LV (880 g kg$~^{-1}$ sand, $20 \mathrm{~g} \mathrm{~kg}^{-1}$ silt, and $100 \mathrm{~g} \mathrm{~kg}^{-1}$ clay) revealed: $\mathrm{pH}\left(\mathrm{CaCl}_{2}\right)=4.1, \mathrm{Si}(0.5$ mol L-1 acetic acid) $=3.0 ; \mathrm{OM}=30 \mathrm{~g} \mathrm{dm}^{-3} ; \mathrm{P}$ anionic exchange resin $=4 \mathrm{mg} \mathrm{dm}^{-3} ; \mathrm{K}, \mathrm{Ca}, \mathrm{Mg}$, and CEC $=2.7 ; 8.3$ and $60.7 \mathrm{mmol}_{\mathrm{c}} \mathrm{dm}^{-3}, \mathrm{~V}$ and $\mathrm{m}=7.5$ and $23 \%$.

Soil samples of $0-20 \mathrm{~cm}$ depth were collected from uncultivated areas to avoid the influence of prior fertilization. The samples were air dried and passed through a five $\mathrm{mm}$ sieve and placed in five liter pots. To standardize particle size, the silicon sources were passed through a sieve 20 (ABNT) yielding particle sizes between 0.30 and $0.84 \mathrm{~mm}$. Thirty days before planting, the silicon sources were thoroughly mixed in the pots with fertilizer $\left(200 \mathrm{mg} \mathrm{kg}^{-1} \mathrm{~N}, 200 \mathrm{mg} \mathrm{kg}^{-1} \mathrm{P}\right.$ and $150 \mathrm{mg} \mathrm{kg}^{-1} \mathrm{~K}$ ) to meet the nutritional needs of the crops.

Ten seeds were sown in each pot for both rice (cultivar IAC 202) and pearl millet (cultivar $\mathrm{BN}$ 12). After formation of the third leaf, the pots were thinned to three plants each. Pots were irrigated every 2 days with deionized water, according to water loss by weight in order to maintain $80 \%$ of water-holding capacity.

Plant material was collected at 140 days after rice sowing and 120 days after pearl millet sowing and separated into shoots (stems and leaves), roots and spikelets and grains. The number of voids to rice plants was also counted. After drying in a forced air oven at $65^{\circ} \mathrm{C}$, the dry weight of shoots, roots and grain and absorbed $\mathrm{Si}$ were measured (ELLIOT;SNYDER, 1991). Homogeneous soil samples were taken before planting and after harvest in order to to evaluate the concentration of soluble $\mathrm{Si}$ in $0.05 \mathrm{~mol} \mathrm{~L}^{-1}$ acetic acid (KORNDÖRFER et al., 1999).

Resulting data were tested by analysis of variance (ANOVA) and F test. Silicon sources were compared by the Tukey test at $5 \%$ of probability and the application rates were evaluated by polynomial regression analysis. 


\section{RESULTS AND DISCUSSION}

After 30 days of incubation, wollastonite and $\mathrm{Ca}$ and $\mathrm{Mg}$ silicate applications linearly increased soluble $\mathrm{Si}$ content in soil (Figures 1 and 2). These results confirm that the materials were reactive, given that $\mathrm{Si}$ was available for rice and pearl millet since sowing. Silicic acid was not reactive due to its low solubility, which was confirmed by Benedito (2004) and Camargo et al.(2007a).
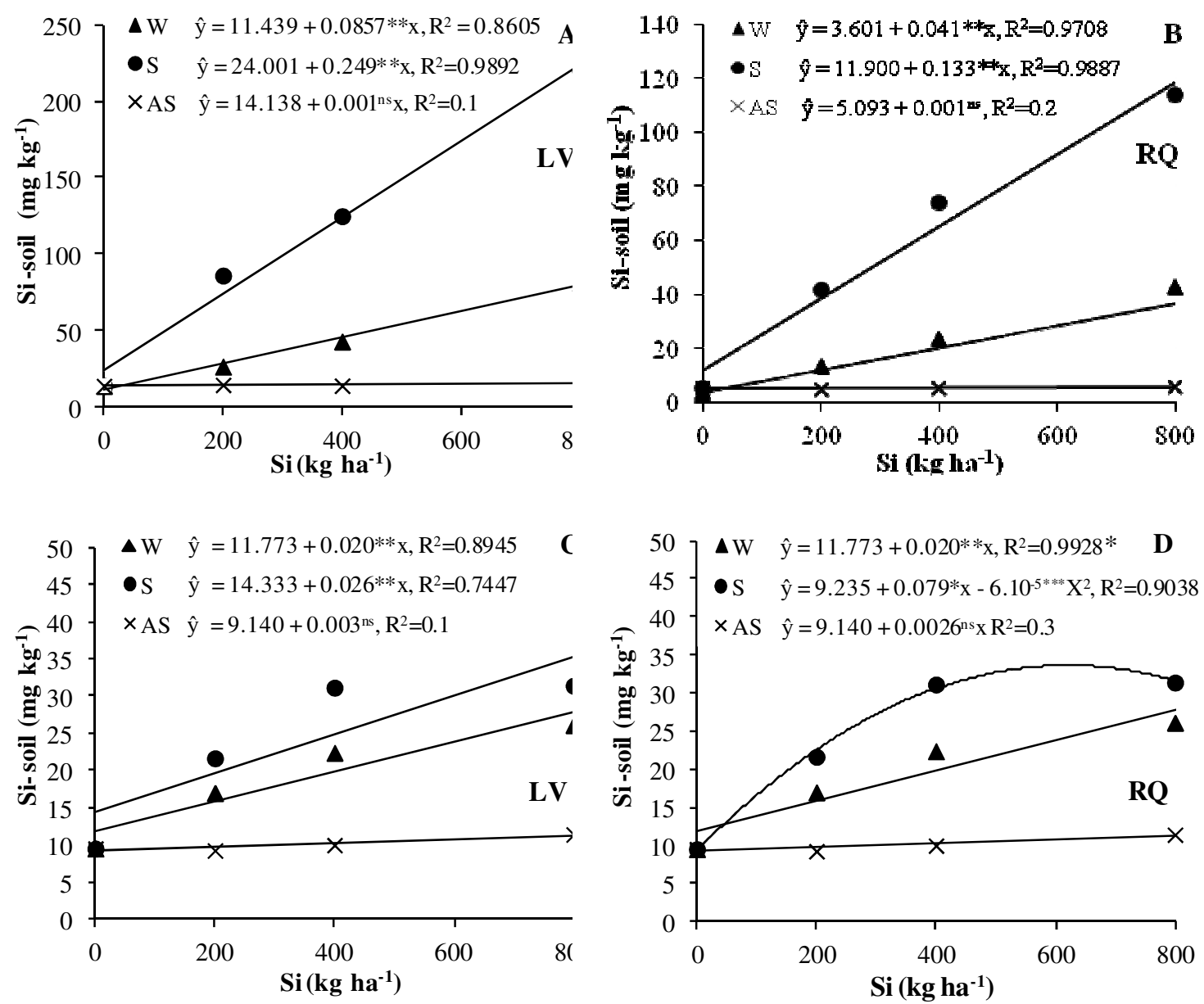

Figure 1. Soluble $\mathrm{Si}$ in $0.5 \mathrm{~mol} \mathrm{~L}^{-1}$ acetic acid of soil samples collected before (A,B) and after (C, D) harvesting of rice grown on a Typic Quartzipsament (RQ) and a Rhodic Haplustox (LV) as a function of the Si application rate of wollastonite $(\mathrm{W}, \mathbf{\Delta}), \mathrm{Ca}-\mathrm{Mg}$ silicate $(\mathrm{S}, \bullet)$ and silica acid $(\mathrm{AS}, \times)$.Significant $(*)$ and non significant $(\mathrm{ns})$ by the $\mathrm{F}$ test $(\mathrm{p}<0.05)$.

Soluble Si content was greater in LV than in RQ (Figures 1 and 2), and was classified as medium and low, respectively (KORNDÖRFER et al., 2001). Higher values for the loamy sandy soil make sense given its higher clay content which is a source of soluble $\mathrm{Si}$, in agreement with Raij;Camargo (1973), Camargo et al., (2007a), Camargo et al. (2007b), and Pereira et al.(2010).

Silicate applied at a rate of $800 \mathrm{~kg} \mathrm{Si} \mathrm{ha}^{-1}$ in $\mathrm{RQ}$ and LV soils, increased $\mathrm{Si}$ soluble in soil linearly by 5 and 6 times, respectively, compared to the control. Higher $\mathrm{Ca}$ silicate values can be attributed to the high capacity of $0.5 \mathrm{~mol} \mathrm{~L}^{-1}$ acetic acid to solubilize $\mathrm{Si}$ from silicate, which was not observed for wollastonite (PEREIRA et al., 2004; CAMARGO et al., 2007 b). 

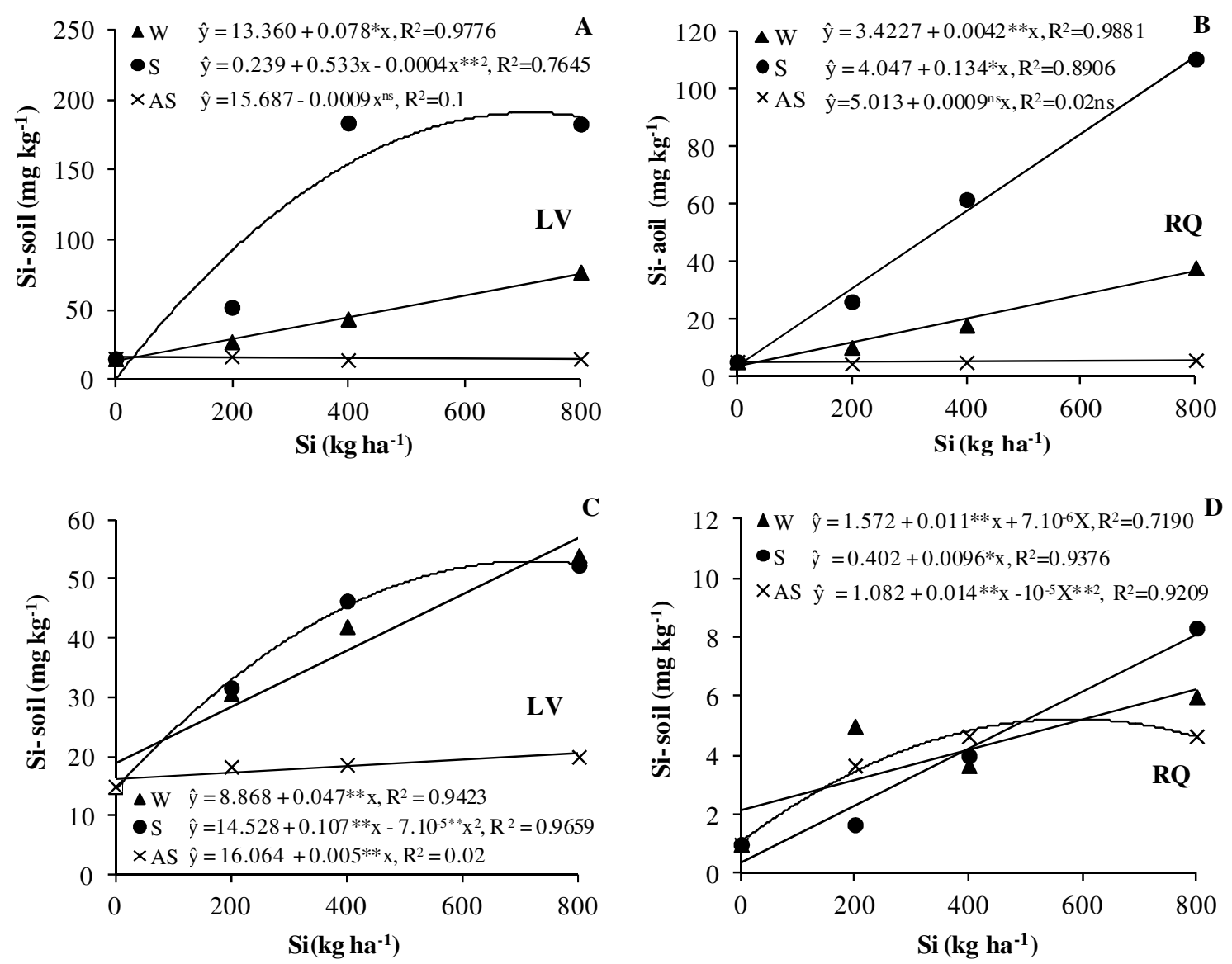

Figure 2. Soluble Si in $0.5 \mathrm{~mol} \mathrm{~L}^{-1}$ acetic acid of soil samples collected before (A,B) and after (C, D) harvesting of pearl millet grown on a Typic Quartzipsament (RQ) and a Rhodic Haplustox (LV) as a function of the Si application rate of wollastonite $(\mathrm{W}, \boldsymbol{\Delta})$, Ca-Mg silicate $(\mathrm{S}, \bullet)$ and silica acid $(\mathrm{AS}, \times)$.Significant $(*)$ and non significant (ns) by the F test $(\mathrm{p}<0.05)$.

The $\mathrm{pH}$ increase with silicate and wollastonite application rates after the harvest of rice and pearl millet was in the range 4.4-5.6, which could lead to an overestimation of the soluble $\mathrm{Si}$ in soils. However, the increased soluble $\mathrm{Si}$ in soil (Figures 1 and 2) was reflected in the shoot dry weight of the two cultures in RQ (Figure 3C, 3F) as well as in the rice grain dry weight (Figure 3B). Because $\mathrm{Ca}$ and $\mathrm{Mg}$ levels were balanced in all plots, the results obtained can be attributed to the applied Si that was absorbed by the plants (Figure 3 $\mathrm{D}, \mathrm{G}$, and $\mathrm{H}$ ). This is also evidenced by the lower $\mathrm{Si}$ content in both soils after harvesting the rice and pearl millet (Figures 1C, $1 \mathrm{D}, 2 \mathrm{C}, 2 \mathrm{D}$ ). Si rates applications of $400 \mathrm{~kg} \mathrm{ha}^{-1} \mathrm{Si}, 500 \mathrm{~kg} \mathrm{ha}^{-1} \mathrm{Si}$ and $935 \mathrm{~kg} \mathrm{ha}^{-1} \mathrm{Si}$ have already increased grain weight (MAUAD et al., 2003; RAMOS et al., 2008), shoot dry weight (PEREIRA et al., 2004) and grain yield (BARBOSA FILHO et al., 2004), respectively.

Reductions in transpiration and increases in photosynthetic activity (Epstein, 2009), although not evaluated here, may have contributed to the increases in plant dry matter observed in this study.
Silicate and wollastonite rates increased $\mathrm{Si}$ uptake linearly in shoot dry weight in rice plants. These results are in agreement with experiments conducted in pots using $400 \mathrm{~kg} \mathrm{ha}^{-1} \mathrm{Si}$ (silicate) in flooding rice (RAMOS et al., 2008), and $500 \mathrm{~kg} \mathrm{ha}^{-1}$ $\mathrm{Si}$ (wollastonite) in upland rice (PEREIRA et al., 2007). Although increases on Si uptake by rice were linear up to $800 \mathrm{~kg} \mathrm{ha}^{-1} \mathrm{Si}$, the maximum grain and shoot dry weight production was obtained in RQ with rates of 542 and $550 \mathrm{~kg} \mathrm{ha}^{-1} \mathrm{Si}$, respectively (Figure 3B and C). This could be explained by the higher Si uptake by shoots compared to grains. Lower Si rates used in other studies provided only increases in Si uptake and grain, but not in shoot dry weight (MAUAD et al.,2003; RAMOS et al., 2008). For the pearl millet, a lower rate $\left(480 \mathrm{~kg} \mathrm{ha}^{-1}\right)$ provided the maximum shoot dry weight (Figure 3 B). Si rates linearly increased root dry weight (Figure 3E) and Si uptake by shoots (Figure 3G, H) but it was lower to Si uptake by rice (Figure 3D). Ca and $\mathrm{Mg}$ silicate also produced greater rice and pearl millet root mass in both soils (Table 1) due to the higher Si content from this source. 

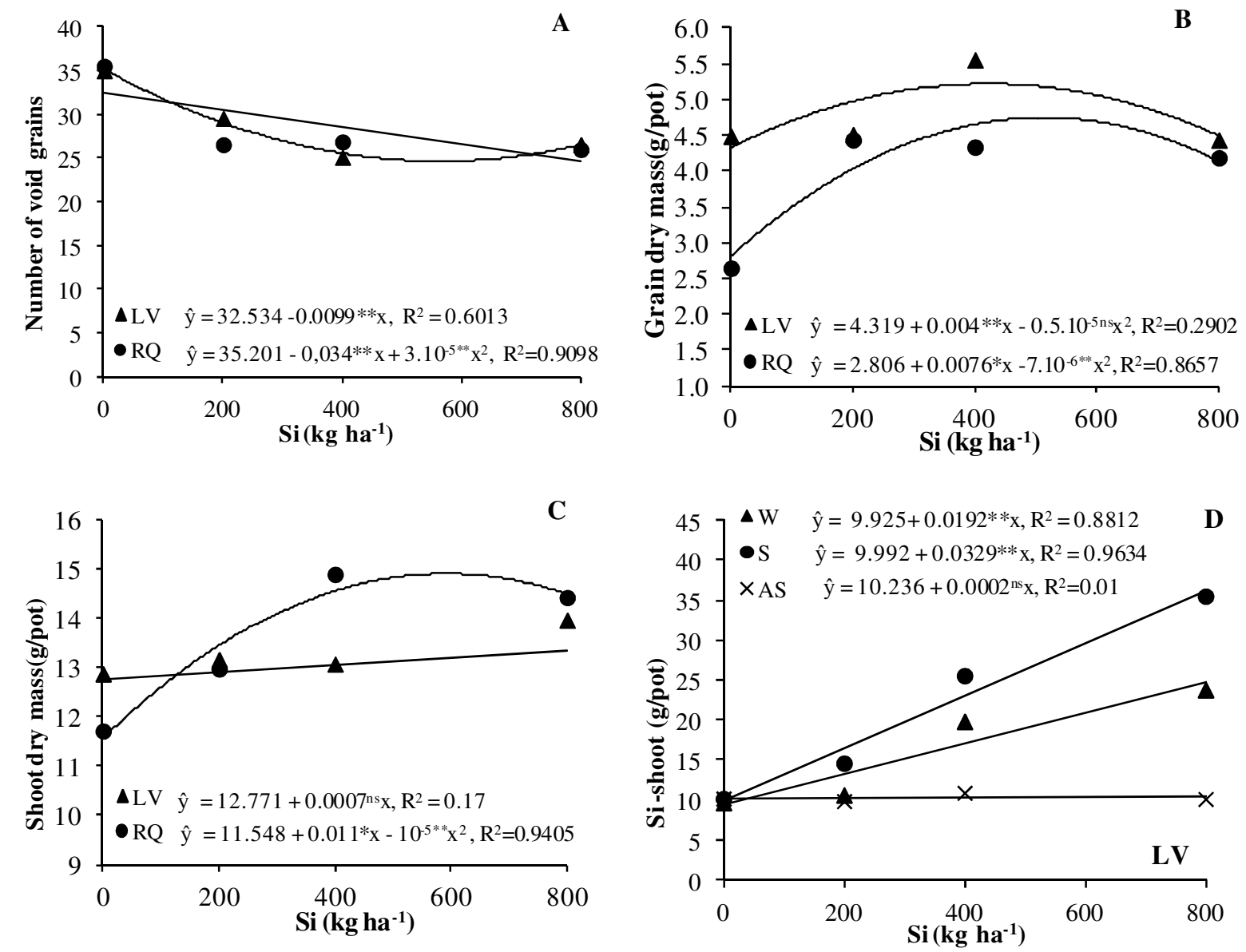

Figure 3. Number of grain void, grain and shoot dry weight, Si by uptake by rice (A-D) grown in Rhodic Haplustox $(\mathrm{LV})$ and Quartzipsament (RQ) with Si rates application of wollastonite $(\mathrm{W}, \mathbf{\Delta}), \mathrm{Ca}-\mathrm{Mg}$ silicate $(\mathrm{S}, \bullet)$ and silica acid (AS, $\times)$.Significant $(*)$ and non significant $(\mathrm{ns})$ by the $\mathrm{F}$ test $(\mathrm{p}<0.05)$.

Differences were also not observed among Si sources (Table 1). This could be related to its higher soluble $\mathrm{Si}$ content compare to RQ soil
(KORNDÖRFER et al., 2001) and consequent lower capacity to respond to Si amendments.

Table 1. Dry weight of grain $(\mathrm{G})$, shoot $(\mathrm{H})$, root ${ }^{\circledR}$ of rice and pearl millet grown in Rhodic Haplustox (LV) and Quartzipsament (RQ) with Si rates application of wollastonite (W), Ca-Mg silicate (S) and silicic acid (AS).

\begin{tabular}{|c|c|c|c|c|c|c|c|c|c|c|c|c|}
\hline \multirow[t]{3}{*}{$\mathrm{Si}$} & \multicolumn{6}{|c|}{ Rice $(\mathrm{g})$} & \multicolumn{6}{|c|}{ Pearl Millet (g) } \\
\hline & \multicolumn{3}{|c|}{$\mathrm{LV}$} & \multicolumn{3}{|c|}{ RQ } & \multicolumn{3}{|c|}{$\mathrm{LV}$} & \multicolumn{3}{|c|}{$\mathrm{RQ}$} \\
\hline & $\mathrm{G}$ & $\mathrm{H}$ & $\mathrm{R}$ & $\mathrm{G}$ & $\mathrm{H}$ & $\mathrm{R}$ & $\mathrm{G}$ & $\mathrm{H}$ & $\mathrm{R}$ & G & $\mathrm{H}$ & $\mathrm{R}$ \\
\hline $\mathrm{W}$ & $4.5 \mathrm{~ns}$ & $13.3 \mathrm{~ns}$ & $7.78 \mathrm{a}$ & $3.7 \mathrm{ab}$ & $12.5 \mathrm{~b}$ & $7.6 \mathrm{ab}$ & $3.1 \mathrm{ab}$ & $14.7 \mathrm{~ns}$ & $6.24 \mathrm{~b}$ & $2.4 \mathrm{~ns}$ & $14.6 \mathrm{a}$ & $7.8 \mathrm{~b}$ \\
\hline $\mathrm{S}$ & $4.9 \mathrm{~ns}$ & $14.2 \mathrm{~ns}$ & $8.49 \mathrm{a}$ & $4.4 \mathrm{a}$ & $14.4 \mathrm{a}$ & $10.7 \mathrm{a}$ & $3.6 \mathrm{a}$ & $15.0 \mathrm{~ns}$ & $6.7 \mathrm{a}$ & $3.1 \mathrm{~ns}$ & $14.4 \mathrm{a}$ & $8.6 \mathrm{a}$ \\
\hline AS & $4.8 \mathrm{~ns}$ & $13.1 \mathrm{~ns}$ & $6.71 \mathrm{~b}$ & $3.5 \mathrm{~b}$ & $12.7 \mathrm{~b}$ & $6.7 \mathrm{~b}$ & $2.8 \mathrm{~b}$ & $12.9 \mathrm{~ns}$ & $5.4 \mathrm{~b}$ & $2.5 \mathrm{~ns}$ & $12.8 \mathrm{~b}$ & $7.4 \mathrm{~b}$ \\
\hline MSD & -..-- & 1.4 & 0.96 & 0.8 & (--.- & 2.4 & 0.6 & 2.1 & 0.9 & --.- & 1.2 & 7.4 \\
\hline
\end{tabular}

$\mathrm{W}=$ wollastonite, $\mathrm{S}=$ calcium and magnesium silicate, $\mathrm{AS}=$ silicic acid; $\mathrm{G}=$ grain, $\mathrm{H}=$ shoot, $\mathrm{R}=$ root. Minimum Significant Difference(MSD): means followed by the same letter in the column did not differ by Tukey's test $(\mathrm{p}<0.05)$. ns=non-significant; * significant at a 5\% significance level.

LV soil did not significantly influence Si uptake or shoot dry weight of rice and pearl millet.

The number of rice grain voids decreased with the $\mathrm{Si}$ applied in both soils (Figure $4 \mathrm{~A}$ ), accompanied by an increase in grain mass (Figure 4 B). Grain void (x) reduction was a consequence of increased silicon uptake in shoots (y) in RQ ( $\mathrm{y}=$ $\left.32.822-0.857 \mathrm{X}, \mathrm{R}^{2}=0.42 *\right)$ and $\mathrm{LV}(\mathrm{y}=33.029$ $\left.=-0.886 \mathrm{X}, \mathrm{R}^{2}=0.35^{*}\right)$. This benefit has already been shown by Mauad et al.(2003) and Barbosa 
Filho et al.(2004) for the rice plants, but the present study showed the direct effect of $\mathrm{Si}$ without the influence of an increase in $\mathrm{pH}$ or $\mathrm{Ca}, \mathrm{Mg}$ contents in the soil.
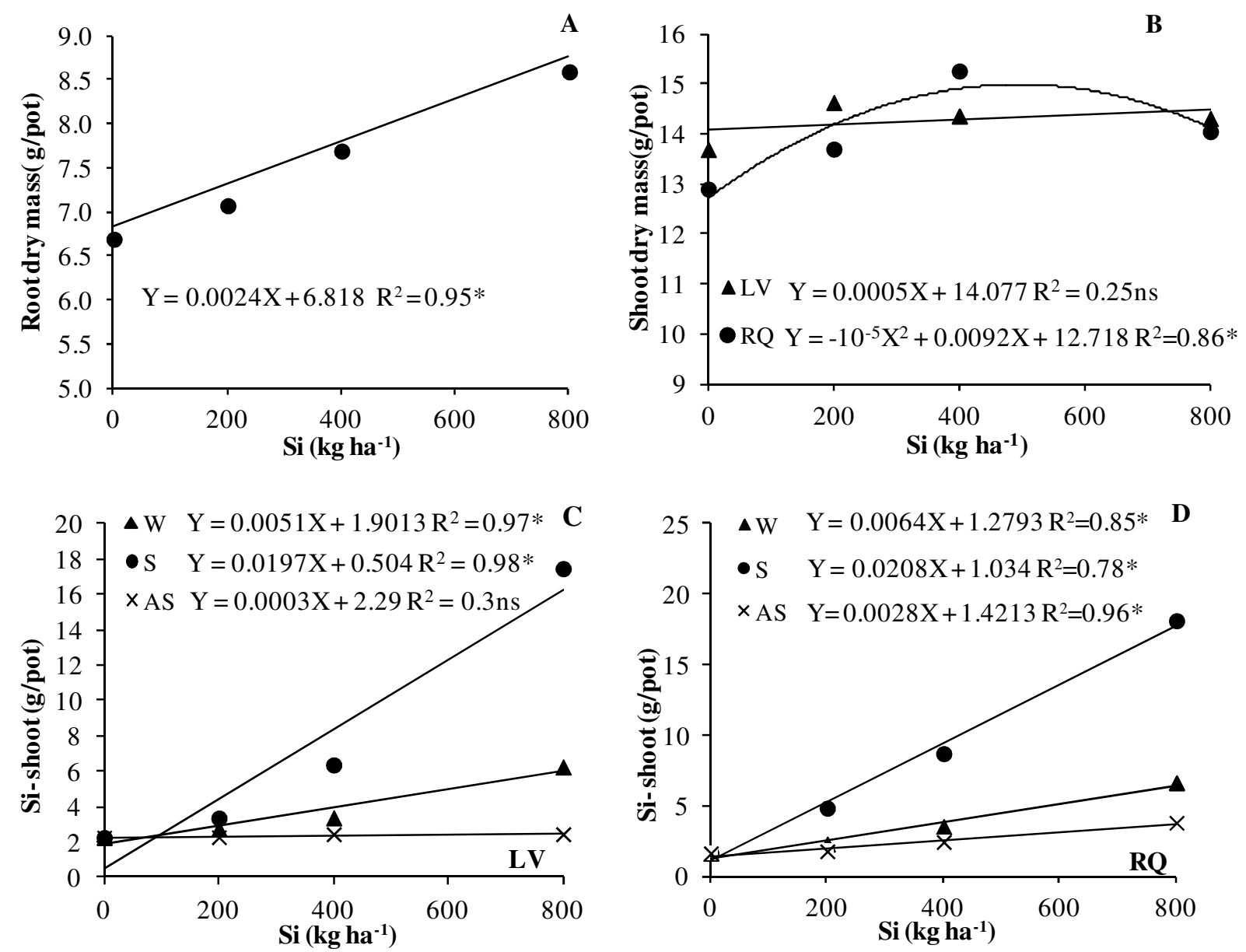

Figure 4. Shoot dry weight of pearl millet (A-D) grown in a Rhodic Haplustox (LV) and a Typic Quartzipsament (RQ) with $\mathrm{Si}$ rates application of wollastonite $(\mathrm{W}, \boldsymbol{\Delta}), \mathrm{Ca}-\mathrm{Mg}$ silicate $(\mathrm{S}, \bullet)$ and silica acid (AS, $\times)$.Significant $(*)$ and non significant $(\mathrm{ns})$ by the $\mathrm{F}$ test $(\mathrm{p}<0.05)$.

The decrease in rice grain voids can be explained by $\mathrm{Si}$ deposition in the rice hull which arose from intense transpiration from the panicle during grain growth (EPSTEIN, 2009). Although no change in shoot dry weight and grain in LV was observed, the Si uptake increased quality, having probably consumed more Si than necessary for the rice grown in this soil.

\section{CONCLUSIONS}

The application of calcium and magnesium silicate and wollastonite led to linear increases in the levels of soluble silicon in Rhodic Haplustox and Quartzipsamment soils and a silicon uptake in the shoots of rice and pearl millet under greenhouse conditions. Maximum rates of Si 542, 550 and 480 $\mathrm{kg} \mathrm{ha}^{-1}$ in RQ soil provided maximum grain yield, shoot dry matter of rice and pearl millet, respectively.

The grain void in rice plants was linearly reduced with $\mathrm{Si}$ application rates and $\mathrm{Si}$ uptake.

\section{ACKNOWLEDGMENTS}

The authors thanks to Brazilian Federal Agency for the Support and Evaluation of Graduate Education (CAPES) for providing a doctoral scholarship to the first author. 
RESUMO: Embora já tenha sido estudada a adubação silicatada em arroz, a maioria dos estudos brasileiros tem focado nos efeitos da correção da acidez de fontes e doses aplicadas e não no fornecimento de Si. Aliado a isso, os efeitos benéficos são raramente associados a outras plantas acumuladoras como o milheto, que é intensamente cultivado nos solos com baixo $\mathrm{Si}$ solúvel da região do Cerrado. O objetivo desse trabalho foi avaliar fontes e doses de silício na produção e qualidade de duas culturas comumente cultivadas (arroz e milheto) em solos de cerrado. Os experimentos foram conduzidos em duas culturas (arroz e milheto) e dois solos (Neossolo Quartzarênico-RQ e Latossolo VermelhoAmarelo-LV) em um delineamento inteiramente casualizado composto de quatro doses de silício equivalentes a 0; 200; 400 e $800 \mathrm{~kg} \mathrm{ha}^{-1} \mathrm{Si}$, três fontes (silicato de cálcio e magnésio-S; wollastonita-W; ácido silícico-AS) e quatro repetições. Os tratamentos receberam a mesma quantidade de $\mathrm{Ca}$ e $\mathrm{Mg}$ para equilibrar as quantidades desses nutrientes dos solos. $\mathrm{O}$ silicato e a wollastonita aumentaram linearmente o Si solúvel em ácido acético 0,5 mol L ${ }^{-1}$ no LV e no RQ e a absorção pela parte aérea do arroz e milheto. Silicato de cálcio e magnésio e a wollastonita aumentaram linearmente o Si solúvel no solo e a absorção de Si pelo arroz e milheto. Máxima produção de grãos e massa seca da parte aérea do arroz e milheto foram obtidas com doses de 542,550 e $480 \mathrm{~kg} \mathrm{ha}^{-1}$ no RQ, respectivamente. As doses de Si proporcionaram redução do número de grãos chochos e aumento na absorção de Si pela parte aérea. O silicato proporcionou maior produção de massa seca comparada a wollastonita nas duas culturas.

PALAVRAS-CHAVE: Adubação. Silicato. Gramíneas.Solo.

\section{REFERENCES}

BARBOSA FILHO, M. P; SNYDER, G. H; FAGERIA, N. K.; DATNOFF, L. E., SILVA, O. F. Silicato de cálcio como fonte de silício para o arroz de sequeiro. Revista Brasileira de Ciência do Solo, Viçosa, v. 25, n. 2, p. 325-330, 2001.

BARBOSA FILHO, M. P; ZIMMERMANN, F. J. P.; SILVA, O. F. Influência da escória silicatada na acidez do solo e na produtividade de grãos do arroz de terras altas. Ciência e Agrotecnologia, Lavras, v. 28, n. 2, p. 323-331, 2004.

CAMARGO, M. S., KORNDÖRFER, G. H.; PEREIRA, H. S. Solubilidade do silício em solos: influência do calcário e ácido silícico aplicados. Bragantia, Campinas, v. 66, n. 4,p. 637-647, 2007a.

CAMARGO, M. S. de, KORNDÖRFER, G. H.; PEREIRA, H. S.; QUEIROZ, A. A.; REIS, C. B. Soil reaction and absorption of silicon by rice. Scientia Agricola, Piracicaba, v. 64, n. 2, p. 176-180, $2007 \mathrm{~b}$.

CARVALHO-PUPPATTO, J. G.; BULL, L. R.; CRUSCIOL, C. A. C. Atributos químicos do solo, crescimento radicular e produtividade do arroz de acordo com a aplicação de escórias. Pesquisa Agropecuária Brasileira, Brasília, v. 39, n. 12, p. 1213-1218, 2004. http://dx.doi.org/10.1590/S0100-204X2004001200008

CARVALHO-PUPPATTO, J. G.; BULL, L. R.; CRUSCIOL, C. A. C.; MAUAD, M.; SILVA, R. H. Efeito de escória de alto forno no crescimento radicular e na produtividade do arroz. Pesquisa Agropecuária Brasileira, Brasília, v. 38, n. 11, p. 1323-1328, 2003. http://dx.doi.org/10.1590/S0100-204X2003001100011

CHEN, W.; YAO, X.; CAI, K.; CHEN, J. Silicon alleviates drought stress of rice plants by improving plant water status, photosynthesis and mineral nutrient absorption. Biological Trace Elements Research, Clifton, v. 142, n. 1, p. 67-76, 2011. http://dx.doi.org/10.1007/s12011-010-8742-x

DEEPAK, G.; MANJUNATH, S.; MANJULA, S.; NIRANJAN-RAJ, N. P.; GEETHA, L.; SHETTY, H. S. Involvement of silicon in pearl millet resistance to downy mildew disease and its interplay with cell wall proline/hydroxyproline-rich glycoproteins. Australasian Plant Pathology, Auckland, v. 37, n. 5, p. 498-504, 2008. http://dx.doi.org/10.1071/AP08047

DETMANN, K. C.; ARAÚJO, W. L.; MARTINS, S. C. V.; SANGLARD, L. M. V. P.; REIS, J. V.; DETMANN, E.; RODRIGUES, F. A.; NUNES-NESI, A.; FERNIE, A. R.; DAMATTA, F. M. Silicon nutrition increases grain yield, which, in turn, exerts a feed-forward stimulation of photosynthetic rates via enhanced 
mesophyll conductance and alters primary metabolism in rice. New Phytologist, Oxford, v. 196, n. 3, p. 752762, 2012. http://dx.doi.org/10.1111/j.1469-8137.2012.04299.x

ELLIOTT, C. L.; SNYDER, G. H. Autoclave-induced digestion for the colometric determination of silicon in rice straw. Journal of Agricultural Food and Chemistry, Davis, v. 39, n. 6, p. 1118-1119, 1991. http://dx.doi.org/10.1021/jf00006a024

EPSTEIN, E. Silicon: its manifold roles in plants. Annals of Applied Biology, Oxford, v. 155, n. 2, p. 155-160, 2009. http://dx.doi.org/10.1111/j.1744-7348.2009.00343.x

HOSSEIN, N. Z.; JELODAR, N. B.; BAGHERI, N. Study of silicon effects on plant growth and resistance to stem borer in rice. Communication Soil Science Plant Analysis, Athens, v. 43, n. 21, p. 2744-2751, 2012. http://dx.doi.org/10.1080/00103624.2012.719972

KORNDÖRFER, G. H.; COELHO, N. M.; SNYDER, G. H.; MIZUTANI, C. T. Avaliação de métodos de extração de silício para solos cultivados com arroz de sequeiro. Revista Brasileira de Ciência do Solo, Viçosa, v. 23, p. 101-106, 1999. http://dx.doi.org/10.1081/PLN-100103804

KORNDÖRFER, G. H.; SNYDER, G. H.; ULLOA, A. M.; PERDOMO, R.; POWELL, C.; DEREN, C.; DATNOFF, L. E. Calibration of soil and plant silicon analysis for rice production. Journal Plant Nutrition, Athens, v. 24, n. 7, p. 1071-1084, 2001.

MARCHESAN, E.; VILLA, S. C. C.; MARZARI,V.; KORNDÖRFER, G. H.; SANTOS, F. M. Aplicação de silício em arroz irrigado: efeito nos componentes da produção. Bioscience Journal, Uberlândia, v. 20, n. 3, p. 125-131, 2004.

MAUAD, M.; CRUSCIOL, C. A. C.; FILHO, H. G.; CORRÊA, J. C. Nitrogen and silicon fertilization of upland rice. Scientia Agricola, Piracicaba, v. 60, n. 4, p. 761-765, 2003. http://dx.doi.org/10.1590/S010390162003000400023

MITANI, N. MA, J. F. Uptake system of silicon in different plant species. Journal Experimental Botany, Oxford, v. 56, n. 414, p. 1255-1261, 2005. http://dx.doi.org/10.1093/jxb/eri121

PEREIRA, H. S.; BARBOSA, N. C.; CARNEIRO, M. A. C.; KORNDÖRFER, G. H. Avaliação de fontes e extratores de silício no solo. Pesquisa Agropecuária Brasileira, Brasília, v. 42, n. 2, p. 239-247, 2007. http://dx.doi.org/10.1590/S0100-204X2007000200013

PEREIRA, H. S.; GAMA, A. J. M.; CAMARGO, M. S.; KORNDÖRFER, G. H. Reatividade de escórias silicatadas da indústria siderúrgica. Ciência e Agrotecnologia, Lavras, v. 34, n. 2,p. 382-390, 2010.

PEREIRA, H. S.; KORNDÖRFER, G. H.; VIDAL, A. A.; CAMARGO, M. S. Silicon sources for the rice plants. Scientia Agricola,Piracicaba, v. 61, n. 5, p. 522-528, 2004.

PEREIRA, H. S.; QUEIROZ, A. A.; MARTINS, M. R.; CAMARGO, M. S.; KORNDÖRFER, G. H. Potencial de uso de agregados siderúrgicos e outras fontes de silício em quatro materiais de solos fase cerrado.

Bioscience Journal, Uberlândia, v. 23, n. 3, p. 17-31, 2007.

RAIJ, B. van; CAMARGO, O. A. Sílica solúvel em solos. Bragantia, Campinas, v. 32, n. 11, p. 223-231, 1973.

RAMOS, L. A.; KORNDÖRFER, G. H.; NOLLA, A. Acúmulo de silício em plantas de arroz do ecossistema de várzea submetido à aplicação de diferentes fontes. Bragantia, Campinas, v. 67, n. 3, p. 751-757, 2008. http://dx.doi.org/10.1590/S0006-87052008000300025 
RANGANATHAN, S.; SUVARCHALA, V.; RAJESH, Y.; SRINIVASA PRASAD, M.; PADMAKUMARI, A. P.; VOLETI, S. R. Effects of silicon sources on its deposition, chlorophyll content, and disease and pest resistance in rice. Biologia Plantarum, Berlin, v. 50, n. 4, p. 713-716, 2006. http://dx.doi.org/10.1007/s10535006-0113-2.

RODRIGUES, P. B.; ROSTAGNO, H. S.; ALBINO, L. F. T.; GOMES, P. C.; BARBOZA, W. A.; SANTANA, R. T. Valores energéticos do milheto, do milho e subprodutos do milho, determinados com frangos de corte e galos adultos. Revista Brasileira de Zootecnia, Viçosa, v. 30, n. 6, p. 1767-1778, 2001.

TATAGIBA, S. D.; RODRIGUES, F. A.; FILIPPI, M. C. C.; SILVA, G. B.; SILVA, L. C. Physiological Responses of Rice Plants Supplied with Silicon to Monographella albescens Infection. Journal Phytopathology, Hoboken, v. 162, n. 9, p. 506-606, 2014. 